\title{
Evaluation of the Combined Effect of Heterodera glycines and Macrophomina phaseolina on Soybean Yield in Naturally Infested Fields with Spatial Regression Analysis and in Greenhouse Studies
}

\author{
H. D. Lopez-Nicora, ${ }^{1,2}$ J. K. Carr, ${ }^{3}$ P. A. Paul, ${ }^{4}$ A. E. Dorrance, ${ }^{4}$ T. I. Ralston, ${ }^{2}$ C. A. Williams, ${ }^{2}$ and T. L. Niblack ${ }^{2, \dagger}$ \\ ${ }^{1}$ Departamento de Producción Agrícola, Universidad San Carlos, Alfredo Seiferheld 4989, Asunción, C.P. 1884, Paraguay \\ ${ }^{2}$ Department of Plant Pathology, The Ohio State University, Columbus, OH 43210, U.S.A. \\ ${ }^{3}$ Department of Geography, The Ohio State University, Columbus, OH 43210, U.S.A. \\ ${ }^{4}$ Department of Plant Pathology, The Ohio State University, Ohio Agricultural Research and Development Center, Wooster, OH 44691, U.S.A. \\ Accepted for publication 8 September 2019.
}

ABSTRACT

\begin{abstract}
Heterodera glycines, the soybean cyst nematode, and Macrophomina phaseolina, causal agent of charcoal rot, are economically important soybean pathogens. The impact and effect of these pathogens on soybean yield in coinfested fields in the Midwest production region is not known. Both pathogens are soilborne, with spatially aggregated distribution and effects. Spatial regression analysis, therefore, is an appropriate method to account for the spatial dependency in either the dependent variable or regression error term from data produced in fields naturally infested with H. glycines and M. phaseolina. The objectives of this study were twofold: to evaluate the combined effect of $H$. glycines and $M$. phaseolina on soybean yield in naturally infested commercial fields with ordinary least squares and spatial regression models; and to evaluate, under environmentally controlled conditions, the combined effect of $H$. glycines and $M$. phaseolina through nematode reproduction and plant tissue fungal colonization. Six trials were conducted in fields naturally infested with $H$. glycines and $M$. phaseolina in Ohio. Systematic-grid sampling was used to determine the population densities of $H$. glycines and M. phaseolina, and soybean yield estimates. Though not used in any statistical analysis, M. phaseolina colony forming units from plant tissue,
\end{abstract}

charcoal rot severity, and $H$. glycines type were also recorded and summarized. In two greenhouse experiments, treatments consisted of $H$. glycines alone, M. phaseolina alone, and coinfestation of soybean with both pathogens. Moran's $I$ test indicated that the yield from five fields was spatially correlated $(P<0.05)$ and aggregated. In these fields, to account for spatial dependence, spatial regression models were fitted to the data. Spatial regression analyses revealed a significant interaction effect between $H$. glycines and $M$. phaseolina on soybean yield for fields with high initial population densities of both pathogens. In the greenhouse experiments, $H$. glycines reproduction was significantly $(P<0.05)$ reduced in the presence of $M$. phaseolina; however, soybean tissue fungal colonization was not affected by the presence of $H$. glycines. The direct mechanisms by which $H$. glycines and M. phaseolina interact were not demonstrated in this study. Future studies must be conducted in the field and greenhouse to better understand this interaction effect.

Keywords: charcoal rot, ecology and epidemiology, nematology, soybean cyst nematode, spatial analysis
The soybean cyst nematode (SCN), Heterodera glycines Ichinohe, is the most economically important pathogen of soybean in the United States (Allen et al. 2017; Koenning and Wrather 2010). Reduction in soybean (Glycine max) yield by H. glycines can range from 30 to $50 \%$, and may occur in the absence of visible symptoms (Chen et al. 2001; Niblack et al. 1992; Wang et al. 2003; Young 1996). Another important pathogen of soybean is the fungus Macrophomina phaseolina (Tassi) Goid., causal agent of charcoal rot (Allen et al. 2017; Mengistu et al. 2015). This fungus is reported to affect more than 500 plant species, including soybean and corn (Zea mays), which are commonly used in crop rotation practices (Mengistu et al. 2015; Mihail and Taylor 1995; Su et al. 2001).

†Corresponding author: T. L. Niblack; niblack.2@osu.edu

Funding: Salaries and research support were provided, in part, by state and federal funds appropriated to the Ohio Agricultural Research and Development Center, The Ohio State University. This material is based upon work that is supported by the United States Department of Agriculture-National Institute of Food and Agriculture under Hatch project entitled Development of Disease Management Strategies for Soybean Pathogens in Ohio [OHO1303]. This project was funded, in part, by soybean producers' check-off dollars through the North Central Soybean Research Program and the Ohio Soybean Council.

*The $e$-Xtra logo stands for "electronic extra" and indicates that supplementary materials are published online.

The author(s) declare no conflict of interest.

(C) 2020 The American Phytopathological Society
Under conducive (hot and dry) environmental conditions, charcoal rot can cause significant soybean yield reduction and is a common disease in the southern United States (Allen et al. 2017; Koenning and Wrather 2010; Mengistu et al. 2015). However, charcoal rot has recently become more regularly observed in the north-central region of the United States (Bradley and del Río 2003; Cummings and Bergstrom 2013; ElAraby et al. 2003; Gearhart et al. 2010; Smith et al. 2014; Yang and Navi 2005).

Both $H$. glycines and $M$. phaseolina are soilborne root pathogens with the ability to survive long term as eggs (commonly enclosed in cysts) and microsclerotia, respectively. Similar to most soilborne pathogens, their distribution in a field can be influenced by several abiotic and biotic factors. Previous studies have reported that the spatial distribution of both $H$. glycines and M. phaseolina is aggregated in the soil (Campbell and van der Gaag 1993; Francl 1986; Gavassoni et al. 2001, 2007; Mihail 1989; Mihail and Alcorn 1987; Olanya and Campbell 1988). Consequently, the damage that these pathogens cause to soybean may not be spatially independent in infested fields but, rather, spatially correlated (Gavassoni et al. 2007; Melakeberhan et al. 2004).

More fields in the Midwest production region have become infested with $H$. glycines since it was first reported in the United States (Tylka and Marett 2014), and the almost ubiquitous presence of $M$. phaseolina results in high numbers of fields concomitantly infested with both pathogens (Lopez-Nicora et al. 2016). The impact and effect of $H$. glycines and $M$. phaseolina on soybean yield in coinfested fields from this region is not known (Romero Luna 
et al. 2017). Todd et al. (1987) evaluated H. glycines-resistant and -susceptible soybean cultivars in fields infested with both $H$. glycines and M. phaseolina and reported a positive correlation between fungal colonization of root tissue and $H$. glycines root densities. Greater yield losses were observed when soybean plants were concomitantly infected by $H$. glycines and $M$. phaseolina than by either one alone. Winkler et al. (1994) reported that $H$. glycinessusceptible soybean cultivars had greater density of $M$. phaseolina in roots when plants were infected with $H$. glycines compared with resistant cultivars. In contrast, there was no interaction but, rather, an additive effect on soybean yield when $H$. glycines was quantified from soil samples obtained at planting and harvest and M. phaseolina from soybean roots at harvest (Todd 1993). Similarly, there was no interaction on soybean yield when population densities of both pathogens were measured in soil (Francl et al. 1988).

To evaluate the effects of both $H$. glycines and $M$. phaseolina on soybean production, observational studies in fields concomitantly infested with both pathogens would be valuable. In observational studies, investigators observe, measure, and record variables of interest (e.g., crop yield, pathogen population densities, climatic factors, and so on) instead of assigning treatments to experimental units. In this type of study, therefore, researchers are not in control of where and how these variables of interest occur (Kutner et al. 2004; Montgomery 2013; Schabenberger and Pierce 2002). A common technique used to evaluate data generated from observational studies is ordinary least squares (OLS) linear multipleregression analysis (Kutner et al. 2004). Multiple-regression models allow for tests of interaction between independent variables (e.g., soilborne pathogens) and their effect on the response variable (e.g., crop yield).

In OLS linear multiple regression, parameter estimates and standard errors are unbiased and efficient as long as the required assumptions (e.g., independent observations, homogeneity of error variance, and normally distributed residuals) are met (Kutner et al. 2004; Liu et al. 2014, 2015). The use of an OLS regression model to assess data from observational studies under violation of statistical assumptions may lead to erroneous conclusions (Hughes 1988; Liu et al. 2014, 2015). If the dependent variable or the OLS regression model residuals are spatially autocorrelated, then the independence assumption is violated, and the OLS regression model will produce biased or inefficient parameter estimates. Spatial dependence can arise in the dependent variable (e.g., soybean yield), the error term (e.g., OLS residuals), or exogenous variables (Anselin et al. 2004; Liu et al. 2014, 2015; Waller and Gotway 2004). Spatial regression analysis (Anselin et al. 2004; Bivand et al. 2013; Liu et al. 2014, 2015; Waller and Gotway 2004; Ward and Gleditsch 2008), therefore, would be an appropriate approach to account for the spatial dependency in either the response variable (e.g., soybean yield) or regression error term from data produced in fields naturally infested with $H$. glycines and $M$. phaseolina.

Therefore, the objectives of this study were to (i) evaluate the combined effect of $H$. glycines and $M$. phaseolina on soybean yield in naturally infested commercial fields with OLS regression and spatial regression models and (ii) evaluate, through nematode reproduction and plant tissue fungal colonization, the combined effect of $H$. glycines and $M$. phaseolina infecting soybean under environmentally controlled conditions in greenhouse experiments.

\section{MATERIALS AND METHODS}

Field experiments: trial locations and soybean cultivars. In total, six different field trials (hereafter referred to as fields 1 to 6 ) were established during 2012, 2013, and 2014 (two fields each year). Trials were located in fields naturally infested with $H$. glycines and M. phaseolina. Five trials (fields 1 to 5) were conducted in commercial soybean fields in Pike and Brown County in southern Ohio, whereas the sixth trial was conducted at the
Waterman Agricultural and Natural Resources Laboratory on the Columbus campus of The Ohio State University. Soybean cultivars, relative maturities, and their responses to $H$. glycines were recorded. Soybean crops were planted and managed with standard, commercial production practices in all trials (Barker et al. 2017).

Field sampling methods. Systematic grid sampling was used to determine the population densities of $H$. glycines and M. phaseolina, and soybean yield estimates. A 10-by-10 grid of contiguous quadrats ( 7.62 by $7.62 \mathrm{~m}$ each) was used in five trials (Fig. 1). In field 6, a 7-by-15 grid of contiguous quadrats ( 7.62 by $7.62 \mathrm{~m}$ each) was used due to space limitations. Wire flags were placed in the center of each quadrat between two soybean rows and represented the middle point of a 2-m-long sampling distance from which soil and plant samples were collected. Plant and soil samples were collected at 100 sites in fields 1 to 5 and at 105 sites in field 6 . Quadrats, therefore, were represented by samples (and data) collected from the area designated by wire flags. The spatial relation of each sampling point within the quadrat grids was recorded. Quadrats from left to right were alphabetically labeled, and those from top to bottom were numerically labeled (Fig. 1). Thus, the spatial position of each sampling point relative to the others was maintained.

Quadrat soil and plant sampling. Soil was sampled within 3 to 4 weeks of planting and at soybean growth stage R8 (Fehr et al. 1971) to determine the initial (Pi) and final (Pf) population densities of $H$. glycines eggs and $M$. phaseolina colony forming units (CFU). In the center of each quadrat, a composite sample of 15 to 20 soil cores was collected with a $2.54-\mathrm{cm}$-diameter cylindrical soil probe (Model LS; Oakfield Apparatus, Fond du Lac, WI, U.S.A.) within a 2-m-long distance between two soybean rows to a depth of 15 to $25 \mathrm{~cm}$. Soil cores were combined in labeled sample bags and placed in insulated containers during transport to the laboratory. Cores in each composite sample were thoroughly mixed and samples were stored in a cold room at $4^{\circ} \mathrm{C}$ for approximately 2 weeks until processed. Additionally, soybean plants were arbitrarily collected from the two soybean rows within the 2-m-long sampling distance described above. These plants were used to quantify $M$. phaseolina in soybean tissue, charcoal rot severity, and soybean yield, as described below.

Data collection from field experiments. Weather data. Monthly ambient temperature (minimum, maximum, and mean) and precipitation data were collected from May to October for fields 1 to 6 from the Parameter-Elevation Regressions on Independent Slopes Model (PRISM) Climate Group (http://www.prism. oregonstate.edu/).

$\mathrm{H}$. glycines and M. phaseolina quantification from soil. Two subsamples of $100 \mathrm{~cm}^{3}$ and $1 \mathrm{~g}$ were obtained from each composite soil sample to determine the population densities of $H$. glycines and M. phaseolina, respectively. $H$. glycines eggs were extracted and quantified as the number of eggs per $100 \mathrm{~cm}^{3}$ of soil according to a standard procedure (Faghihi and Ferris 2000). M. phaseolina CFU were quantified from each 1-g subsample of air-dried soil, as described by Mengistu et al. (2009). Details of the H. glycines and M. phaseolina quantification methods are given in Supplementary File S1.

M. phaseolina quantification from plant tissue and charcoal rot severity. A subsample of 5 plants from 25 plants collected for yield analysis (described below) was uprooted and the lower portion of the stems and roots were removed, placed in sample bags, and used to assess $M$. phaseolina colonization and to quantify the density of M. phaseolina per gram of dry tissue. The upper portion of these five plants were returned to the bundle of plants for yield analysis.

Lower stems and roots from plants collected at R8 were air dried and cross sectioned. Intensity of $M$. phaseolina colonization was assessed on a 1-to-5 scale, as described by Mengistu et al. (2007). After the visual assessment of $M$. phaseolina colonization in root tissue (a proxy for charcoal rot severity), stem and root sections were pulverized through a $600-\mu \mathrm{m}$-aperture screen using a Wiley mill (Model 3379-K05; Thomas Scientific, Swedesboro, NJ, U.S.A.), and CFU of $M$. phaseolina were determined per gram of 
plant tissue (Mengistu et al. 2007). To quantify CFU of $M$. phaseolina from plant tissue rather than $1 \mathrm{~g}$ of soil, a $0.05 \mathrm{-g}$ subsample of ground soybean tissue was used as starting material and final CFU counts were reported per gram of soybean tissue. In 2012 and 2013, M. phaseolina colonization was visually assessed from plants on a 1-to-5 scale on samples from 10 quadrats (the ones constituting the diagonal) within each field. In 2014, samples from all quadrats within each field were assessed for M. phaseolina colonization. In 2012, M. phaseolina was not quantified in plant tissue. In 2013 and 2014, a subsample of 5 plants from 25 plants collected for yield analysis, as described above, was used to quantify M. phaseolina.

H. glycines virulence profile. Subsamples of soil from each quadrat within a field were combined to form one composite sample for each trial location. H. glycines type (HG type) tests (Niblack et al. 2002) were conducted to determine the virulence profile of the H. glycines populations from each field. Details for the HG type protocol are presented in Supplementary File S1.

The HG type of each population was assigned based on the calculated female index (FI). An indicator line with an FI $\geq 10$ would be considered a compatible host for that particular population (Niblack et al. 2002; Tylka 2016). For example, if an H. glycines population produces FI $\geq 10$ on PI 88788, PI 209332, and PI 548316, then it is an HG type 2.5.7 (Niblack et al. 2002). An HG type 0 , on the other hand, is one that produces no FI $\geq 10$.

$H$. glycines and M. phaseolina $\mathrm{Pf}$ in soil, M. phaseolina $\mathrm{CFU}$ from plant tissue, charcoal rot severity (evaluated with a 1-to-5 ordinal scale), and HG type were not used in any statistical analysis. These variables were collected, summarized, and used as internal controls to better understand results from the statistical analyses.

Soybean harvest and yield data. Twenty-five soybean plants were collected from each sampling quadrat (plot) and hand threshed with a static thresher (LD 350; Wintersteiger Inc., Salt Lake City, UT, U.S.A.). Soybean seed weight was determined and seed moisture content was measured with a portable moisture tester (Harvest Hand; Dickey-John Corporation, Auburn, IL, U.S.A.). Final weight was adjusted to $13 \%$ moisture and yield estimated as grams per plant.

Field data analysis. Standard OLS, spatial error, and spatial lag multiple-regression models were fitted to data from each trial. Soybean yield (grams per plant) from each quadrat was the dependent (or response) variable, and the independent (or explanatory) variables were $H$. glycines $\mathrm{Pi}$ (eggs per $100 \mathrm{~cm}^{3}$ of soil), M. phaseolina $\mathrm{Pi}$ (CFU per gram soil), and the cross-product term $H$. glycines $\times M$. phaseolina for interaction effect. $H$. glycines eggs and $M$. phaseolina CFU were transformed to natural log values prior to analysis to stabilize variance. Natural log-transformed data were subsequently mean-centered to alleviate multicollinearity generated when the cross-product term $(H$. glycines $\times$ M. phaseolina $)$ was included in the model for the interaction effect (Kutner et al. 2004; Vittinghoff et al. 2012). Regression models from fields in which a significant interaction was not detected were fitted to data excluding the interaction coefficient. $H$. glycines eggs and M. phaseolina $\mathrm{CFU}$ were natural log-transformed prior to analysis to stabilize variance; however, in the absence of the interaction term, variables were not mean-centered.

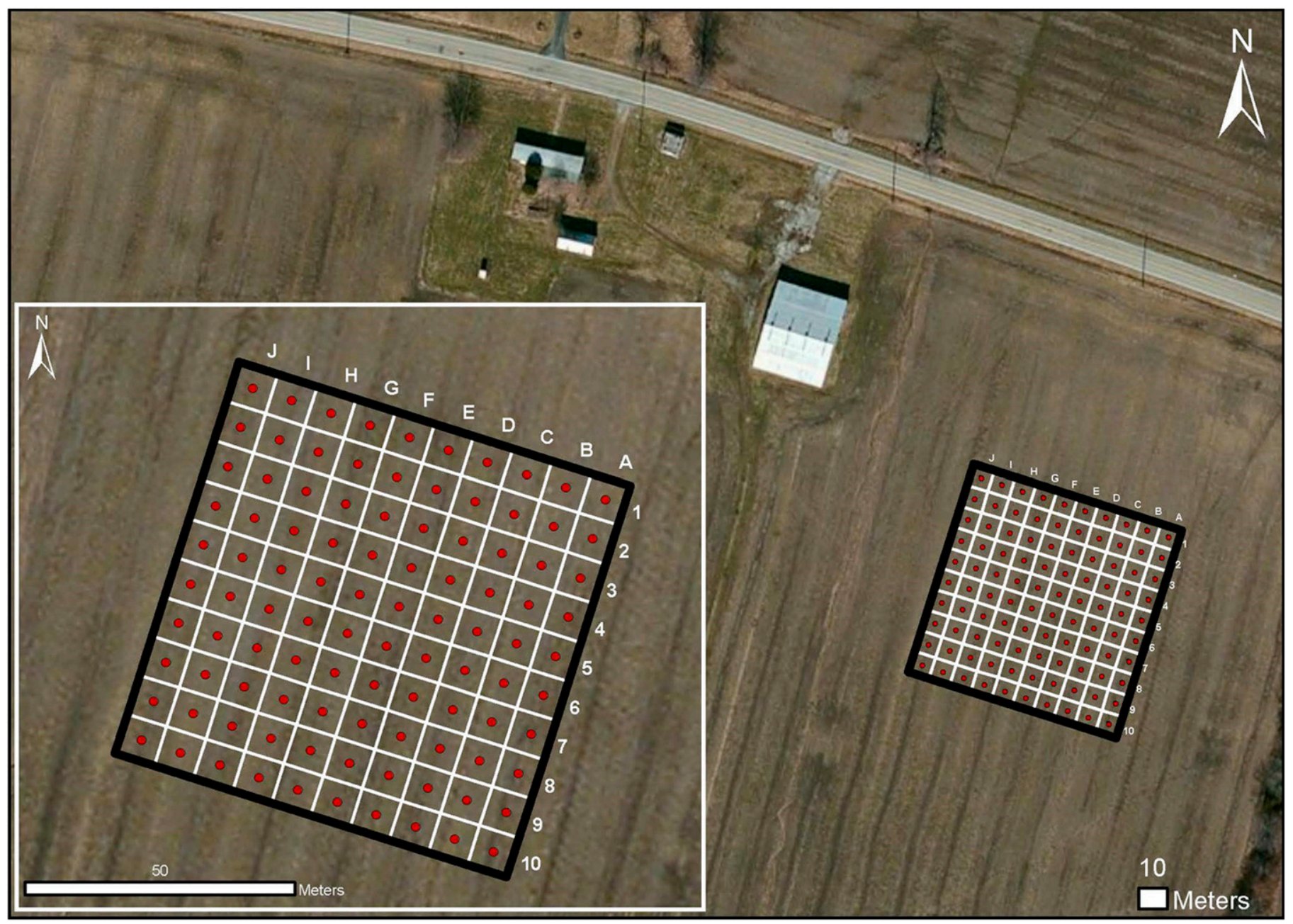

Fig. 1. Layout of a 10-by-10 grid (enlarged in the inset) of contiguous quadrats ( 7.62 by $7.62 \mathrm{~m}$ ) in field 4 . Spatial relation between each quadrat was recorded by labeling files and ranks alphabetically (A to J) and numerically (1 to 10), respectively. Samples were collected from the center of each quadrat (red dot). 
Assessing model assumptions. Residuals from the fitted models were plotted against the predicted values to assess homoscedasticity. Normal distribution of residuals was assessed with ShapiroWilk test and normal probability plots. Variance inflation factor (VIF) was used to check for multicollinearity (Kutner et al. 2004). Maximum VIF values exceeding 10 or mean VIF values significantly greater than one were considered indications of collinearity between the independent variables (Kutner et al. 2004).

Independence in the observations and the residuals was also assessed. Moran's I test for spatial autocorrelation was applied to both the dependent variable (i.e., yield) and the OLS multipleregression residuals. Significant values of Moran's $I(P<0.05)$ on the OLS residuals or the response variable were evidence of spatial autocorrelation and justified the implementation of spatial rather than OLS regression models to data with spatial structure (i.e., lack of independence). Furthermore, Moran's I test was applied to the independent variables (i.e., H. glycines and M. phaseolina $\mathrm{Pi}$ in soil) to examine the spatial pattern of these pathogens in each field.

Model selection. Akaike's information criterion (AIC) was obtained after fitting OLS, spatial error, and spatial lag regression models, and used to select the model that most efficiently summarized the data. Therefore, three AIC values were produced for each field, each corresponding to one of the three regression models. Subsequently, the regression model with the lowest AIC was considered the most appropriate for the conditions of that particular field (Kutner et al. 2004).

Details of standard OLS, spatial error, and spatial lag regression models are provided in Supplementary File S1. Likewise, details of the spatial weight matrix W used to obtain Moran's I and to fit the spatial regression models mentioned above are also provided in Supplementary File S1.

Computation methodology. Geographic representation of the field quadrats was constructed with the Create Fishnet tool in ArcGIS 10.2 (ArcGIS; ESRI, Redlands, CA, U.S.A.). The resulting shapefile was read into $R$, version 3.5.1 (R Core Team 2018), via the read.shapefile and readShapePoly functions from $\mathrm{R}$ packages 'shapefiles' (Stabler 2013) and 'maptools' (Bivand and Lewin-Koh 2018), respectively. All spatial analyses, including construction of queen contiguity spatial weight matrix $\mathrm{W}$ (poly2nb and nb2listw), Moran's I analysis (moran.test and lm.morantest), and computation of spatial error and lag models (errorsarlm and lagsarlm) were done via functions available in the R package 'spdep' (Bivand et al. 2013). The package 'stats' (R Core Team 2018) was used to fit standard OLS regression model using the $l m$ command and to assess regression diagnostics using the $\mathrm{R}$ commands qqplot (to evaluate normal distribution of the residuals), shapiro.test (to test normality), and AIC (to obtain the AIC). From the package 'faraway' (Faraway 2016), the vif command was used to obtain the VIF and, from the package 'graphics' (R Core Team 2018), the command plot was used to plot residuals against predicted variables.

Greenhouse experiments. Two greenhouse experiments were conducted in October (experiment 1) and December (experiment 2) 2018. H. glycines- and M. phaseolina-susceptible soybean cultivar Williams 82 was used in both experiments. Constant conditions were maintained in the greenhouse and ambient temperature and humidity did not vary greatly with the external conditions. Most importantly, water tables were used in the greenhouse to maintain the plant rhizosphere at a constant temperature. Water tables are wooden boxes with a pond liner, filled with water and kept at a constant temperature $\left(27^{\circ} \mathrm{C} \pm 1^{\circ} \mathrm{C}\right)$ using a refrigerating and heating system. Water in the greenhouse was also set at a constant temperature $\left(27^{\circ} \mathrm{C}\right.$ for this study) and used to water the plants when needed.

H. glycines inoculum. An $H$. glycines population (designated WM001-SCN), HG type 2.5.7. (Table 1), was obtained from field 6 at the Waterman Agricultural and Natural Resources Laboratory of The Ohio State University in Columbus, $\mathrm{OH}$ and used as inoculum in the greenhouse experiments. Population WM001-SCN was increased and maintained in the greenhouse at $27^{\circ} \mathrm{C}$ for 30 days with a 16-h photoperiod on susceptible soybean cultivar Williams 82. After 30 days, $H$. glycines eggs were collected as previously described, and diluted in sterile water to approximately 2,500 eggs/ml.

M. phaseolina inoculum. A single $M$. phaseolina isolate (designated Br007-Mp) was obtained from a symptomatic soybean plant collected from field 4 in Brown County, OH. Pure Br007-Mp isolates were used to produce M. phaseolina-infested Japanese millet seed (Echinichloa frumentaceae), as described by Mengistu et al. (2007). Details for the production of M. phaseolina-infested Japanese millet seed are given in Supplementary File S1.

A sieve (250- $\mu \mathrm{m}$ aperture) containing $15 \mathrm{~g}$ of $M$. phaseolinainfested millet seed was placed on top of nested $150-\mu \mathrm{m}$ - over 45 $\mu \mathrm{m}$-aperture sieves. Microsclerotia were dislodged from colonized millet seed with high-pressure water spray (Model B-0100-32H; T\&S Brass, Travelers Rest, SC, U.S.A.) and collected on the $45-\mu \mathrm{m}-$ aperture sieve. Washed millet seed and debris retained on the

TABLE 1. Heterodera glycines and Macrophomina phaseolina population densities, H. glycines reproduction factor (RF), charcoal rot severity, soybean yield, and H. glycines virulence profile for each field

\begin{tabular}{|c|c|c|c|c|c|c|c|c|}
\hline \multirow[b]{2}{*}{ Field $^{c}$} & \multicolumn{2}{|c|}{ H. glycines $^{\mathrm{a}}$} & \multicolumn{4}{|c|}{ M. phaseolina ${ }^{\mathrm{b}}$} & \multirow[b]{2}{*}{ Yield $^{\mathrm{d}}$} & \multirow[b]{2}{*}{ HG type } \\
\hline & $\mathrm{Pi}$ & $\overline{\mathrm{RF}}$ & $\mathrm{Pi}$ & $\mathrm{Pf}$ & Root & $\overline{\text { Severity }}$ & & \\
\hline \multicolumn{9}{|l|}{2012} \\
\hline 1 & 48.8 & 15.1 & 37.7 & 25.2 & $\ldots$ & 3.3 & 10.5 & 2.5 .7 \\
\hline \multicolumn{9}{|l|}{2013} \\
\hline 3 & 965.2 & 6.4 & 20.0 & 14.1 & $12,164.0$ & 1.3 & 13.0 & 2.5 .7 \\
\hline 4 & $2,984.4$ & 2.6 & 53.6 & 39.0 & $56,553.0$ & 2.1 & 11.1 & 5.7 \\
\hline $\begin{array}{c}2014 \\
5 \\
6\end{array}$ & $2,713.9$ & 6.8 & 45.2 & 36.3 & $2,161.2$ & 2.5 & 10.2 & 2.5 .7 \\
\hline
\end{tabular}

a $\mathrm{Pi}=$ mean of Heterodera glycines initial population $(\mathrm{Pi})$ in soil reported in eggs per $100 \mathrm{~cm}^{3}$ of soil. $H$. glycines $\mathrm{RF}=$ ratio between $H$. glycines final population (Pf) to Pi in soil $(\mathrm{Pf} / \mathrm{Pi})$.

${ }^{\text {b }} \mathrm{Pi}$ and $\mathrm{Pf}=$ mean of $M$. phaseolina $\mathrm{Pi}$ and Pf, respectively, in soil reported in CFU per gram of soil. Root $=$ mean of $M$. phaseolina in soybean lower stem and root reported in CFU per gram of soybean tissue. No roots were processed from fields 1 and 2 in 2012. Severity = charcoal rot severity rating using a 1-to-5 rating scale (Mengistu et al. 2007), where $1=$ no microsclerotia visible in tissue, $2=$ few visible microsclerotia in tissue, $3=$ partial discoloration of vascular tissue with few visible microsclerotia, $4=$ discoloration of vascular tissue with microsclerotia embedded in tissue, and $5=$ vascular tissue darkened due to high numbers of microsclerotia both inside and outside of the stem and root tissues.

c Year and field trial.

d Soybean yield estimates in grams per plant.

${ }^{\mathrm{e}} \mathrm{HG}$ type $=H$. glycines virulence profile from each field; 2 indicates $>10 \%$ reproduction on PI 88788,5 indicates $>10 \%$ reproduction on PI 209332 , and 7 indicates $>10 \%$ reproduction on PI 548316. 
$250-\mu \mathrm{m}$ - and 150- $\mu \mathrm{m}$-aperture sieves were discarded. Microsclerotia were combined with $100 \mathrm{ml}$ of $0.5 \%$ sodium hypochlorite (i.e., $10 \%$ bleach) and agitated in an orbital shaker at $200 \mathrm{rpm}$ for $1 \mathrm{~min}$. The mixture was then poured over a $45-\mu \mathrm{m}$-aperture sieve and rinsed well with distilled water. Finally, M. phaseolina microsclerotia were diluted in sterile water at an inoculum density of approximately $10,000 \mathrm{microsclerotia} / \mathrm{ml}$. To confirm the viability and purity of the inoculum, $1 \mathrm{ml}$ of the solution containing M. phaseolina microsclerotia was delivered onto Petri dishes containing potato dextrose agar and placed in an incubator at $27^{\circ} \mathrm{C}$ with no light for 2 to 3 days.

Greenhouse experimental design, soil infestation, and data collection. The experimental design consisted of four treatments arranged in a completely randomized design with 10 replicates. Treatments were soil infested with $H$. glycines, soil infested with $M$. phaseolina, soil coinfested with both pathogens, and an uninoculated control. An experimental unit was a single PVC tube ( $3 \mathrm{~cm}$ in diameter by $15 \mathrm{~cm}$ in length) filled with $100 \mathrm{~cm}^{3}$ of pasteurized soil substrate. A mixture $(3: 1 \mathrm{vol} / \mathrm{vol})$ of pasteurized sand-Turface MVP (Turface Athletics Inc., Buffalo Grove, IL, U.S.A.) was used as soil substrate in both experiments. For each tube, a hole was produced in the soil into which the treatment was delivered and a uniform-sized 2-day-old seedling of Williams 82 was planted. Subsequently, tubes were randomized in plastic containers and placed in water tables for 30 days at $27^{\circ} \mathrm{C}$ with a $16-\mathrm{h}$ photoperiod. The water table served as a water bath to keep the rhizosphere at a constant temperature. Plants were watered every day to keep the soil moist while avoiding saturation.

The $H$. glycines treatment received $1 \mathrm{ml}$ of the WM001-SCN inoculum suspension (containing approximately 2,500 H. glycines eggs) per tube. Subsequently, single soybean seedlings were transplanted into each tube. For the $M$. phaseolina treatment, $1 \mathrm{ml}$ of the Br007-Mp inoculum suspension (containing approximately $10,000 \mathrm{M}$. phaseolina microsclerotia) was delivered to each tube. The $H$. glycines and $M$. phaseolina coinfestation treatment consisted of both inoculation methods described above applied to the same experimental unit (i.e., 2,500 H. glycines eggs and 10,000 $M$. phaseolina microsclerotia delivered per tube). Finally, the uninoculated control consisted of tubes filled with pasteurized soil, no pathogen added, and soybean seedlings planted.

Plants in each tube were removed and soil was gently washed from roots. Each plant was held by the shoots and the root portion was placed on nested $850-\mu \mathrm{m}$ - over $250-\mu \mathrm{m}$-aperture sieves. Highpressure water was applied to the roots to dislodge $H$. glycines females, which were collected in the $250-\mu \mathrm{m}$-aperture sieve, counted, and reported as $H$. glycines females per plant (i.e., experimental unit).

Washed plants were then immersed in $0.5 \%$ sodium hypochlorite for $1 \mathrm{~min}$, rinsed in distilled water for $3 \mathrm{~min}$, and dried with paper towels. Surface-sterilized plants were placed in labeled paper bags and air dried. Once completely dried, plants were weighed and ground, and $0.1 \mathrm{~g}$ of dried tissue was plated to determine M. phaseolina CFU per gram of dry tissue. Each datum was standardized using its corresponding plant dry weight, and M. phaseolina CFU per plant (i.e., experimental unit) was reported.

Greenhouse data analysis. Two dependent variables were obtained from each experiment and analyzed separately. Number of $H$. glycines females per plant was one dependent variable with three treatments: $H$. glycines alone, $H$. glycines- $M$. phaseolina coinfestation, and control. The other dependent variable was $M$. phaseolina CFU per plant, also with three treatments: $M$. phaseolina alone, $H$. glycines-M. phaseolina coinfestation, and control. H. glycines females and $M$. phaseolina CFU per plant were analyzed separately with a generalized linear mixed model (GLMM) in R, version 3.5.1 (R Core Team 2018).

$H$. glycines female and $M$. phaseolina $\mathrm{CFU}$ counts were assumed to follow a Poisson distribution and were each analyzed using a Poisson GLMM, with treatments as fixed effect and experiment runs as random effect. The assumed Poisson distribution was tested and, under violation of the mean-variance equality assumption, the model was refitted using an alternative distribution, the negative binomial, with an extra parameter to account for overdispersion.

Based on results from initial analyses, when $H$. glycines female count was considered the dependent variable, data from each experiment were analyzed separately. On the other hand, when M. phaseolina CFU count was considered the dependent variable, data from each experiment were pooled and analyzed together.

Likelihood ratio and goodness-of-fit tests as well as AIC values were used to assess the fit of each model. Significant differences were declared at an $\alpha$ level of 0.05 . R packages used in the analyses included 'stats' (R Core Team 2018), 'MASS' (Venables and Ripley 2002), 'Ime4' (Bates et al. 2015), 'Imtest' (Zeileis and Hothorn 2002), 'ggplot2' (Wickham 2009), and 'tidyverse' (Wickham 2016).

\section{RESULTS}

Soilborne pathogen population densities and soybean response. Environmental conditions and soybean yield. In this study, monthly average ambient temperature did not exceed $27^{\circ} \mathrm{C}$ in any of the fields (Supplementary Fig. S1). Moreover, maximum temperatures never exceeded $33^{\circ} \mathrm{C}$ in any field. Rainfall was lowest in 2012; however, total precipitation per month exceeded $36 \mathrm{~mm}$ in each field over the course of the study. Average soybean yield per field ranged from 10 to $14 \mathrm{~g} /$ plant (Table 1).

Soilborne pathogen population densities. Overall, Pi densities of H. glycines were $<1,000$ eggs per $100 \mathrm{~cm}^{3}$ of soil in fields 1 to 3 and $>2,000$ eggs per $100 \mathrm{~cm}^{3}$ of soil in fields 4 to 6 (Table 1). With the exception of fields 1 and $6, H$. glycines was detected in all quadrats within each field at the beginning of the season. In field 1, $H$. glycines was not detected in $51 \%$ of the quadrats, while $17 \%$ of the quadrats in field 6 had no detectable $H$. glycines.

The nematode virulence profile for these fields was either HG type 2.5.7 or HG type 5.7 (Table 1). Reproduction factor (RF), a ratio of $\mathrm{Pf}$ to $\mathrm{Pi}$ density $(\mathrm{Pf} / \mathrm{Pi})$, indicated that the $H$. glycines population increased in each field approximately 2 - to 15 -fold at the end of the season. Soybean cultivars planted in each field were labeled resistant to $H$. glycines (Supplementary Table S1). The $H$. glycines resistance response was specific to $\mathrm{HG}$ type 0 (race 3 ) and 1.3- (race 14).

M. phaseolina $\mathrm{Pi}$ densities in these fields ranged from approximately 20 to $60 \mathrm{CFU} / \mathrm{g}$ of soil at the first sampling and declined at the end of the season (Table 1). At harvest, charcoal rot symptoms were observed on stems in fields 1 and 6 (Table 1). In field 1, symptoms were more prevalent and evident (severity ratings ranging from 1 to 5) whereas, in field 6, symptoms were more sporadic and less severe, and only evident under close inspection of lower stems. In fields 3 and 4, M. phaseolina CFU per gram of soybean root tissue was greater from plants with low charcoal rot severity ratings (Table 1). Roots were not processed for M. phaseolina quantification in soybean tissue at harvest for fields 1 and 2, the first year of the study.

Regression model, spatial dependence, and interaction effect. OLS multiple-regression model assumptions. After each model was fit, the residual's normal distribution and homoscedasticity assumptions were met. Similarly, a lack of multicollinearity in the independent variables was verified based on VIF values. Before mean-centering the independent variables $(H$. glycines and $M$. phaseolina) and before including the interaction term (H. glycines $\times M$. phaseolina), the mean VIF values for each model fitted to data from each field did not exceed 1.09, indicating that $H$. glycines and $M$. phaseolina $\mathrm{Pi}$ were not linearly related. When the interaction term was included, the mean VIF values for the six regression models ranged between 21.75 and 141.47. After meancentering $H$. glycines and $M$. phaseolina $\mathrm{Pi}$, and including the interaction term of mean-centered variables, the mean VIF values 
for the six regression models corresponding to each field ranged between 1.01 and 1.63 .

Moran's $I$ values for spatial autocorrelation test on soybean yield, OLS residuals, and $H$. glycines and $M$. phaseolina $\mathrm{Pi}$ in soil are presented in Supplementary Table S2. Significant spatial autocorrelation in both the dependent variable and OLS residuals was observed in all fields, except field 3 . In field 2, for example, a strong positive spatial autocorrelation (i.e., clustering of similar values) in both yield response $(I=0.480, P<0.001)$ and OLS residuals $(I=0.454, P<0.001)$ was observed (Fig. 2). Moran's $I$ values did not differ from zero for yield $(P=0.058)$ and OLS residuals $(P=0.166)$ in field 3 ; therefore, observations from this field were spatially independent and arranged at random (Fig. 2). The spatial distribution of $H$. glycines and $M$. phaseolina Pi densities in soil was also examined. Significant Moran's $I$ values for both soilborne pathogens were positive, indicating aggregation or clustering of the observations in the field (Fig. 3).

Model selection. The OLS and the two spatial regression models were compared based on AIC values. The standard OLS regression
A
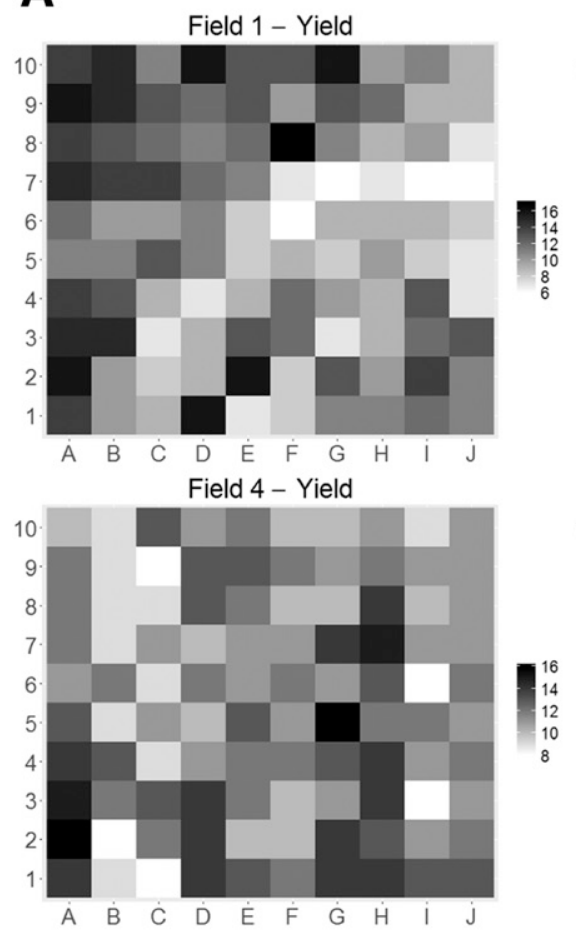
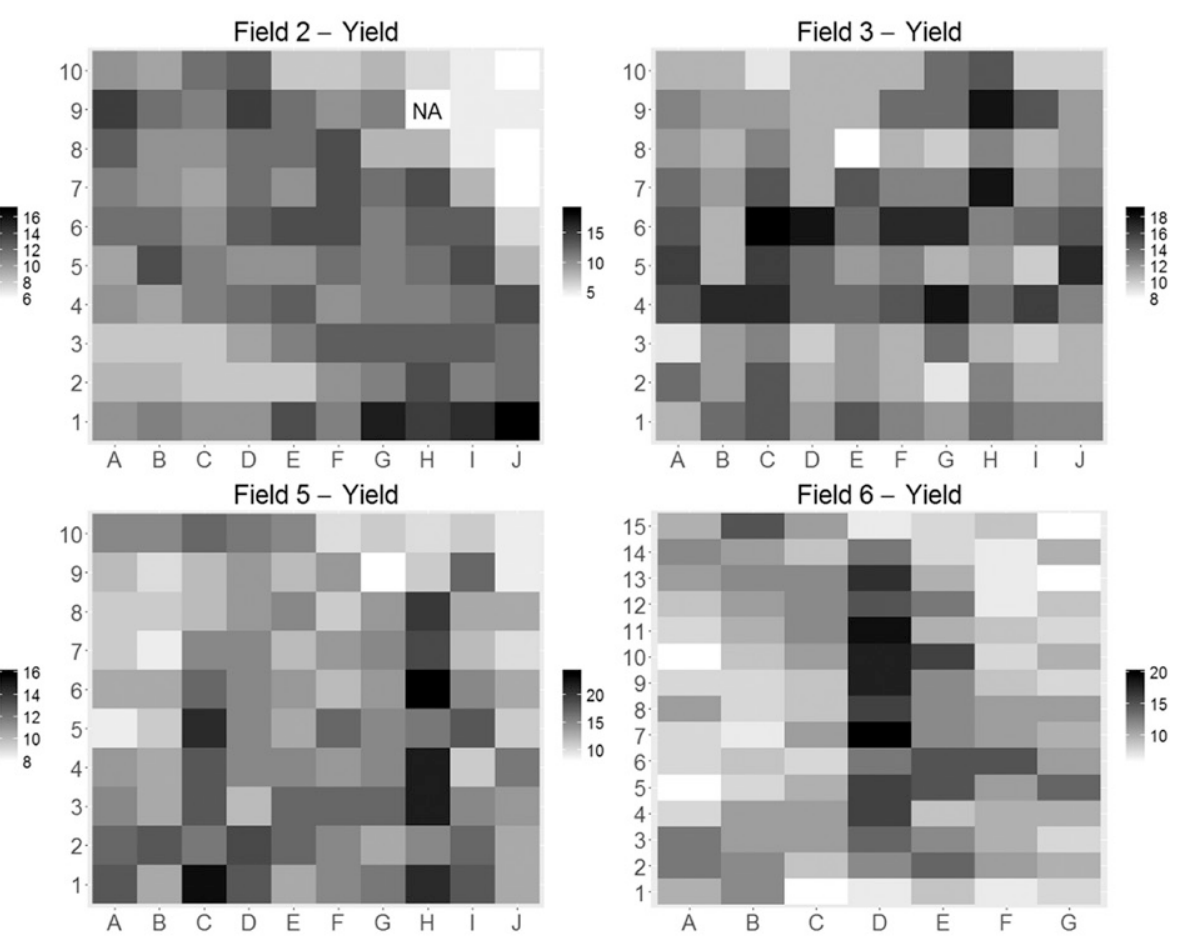

\section{B}
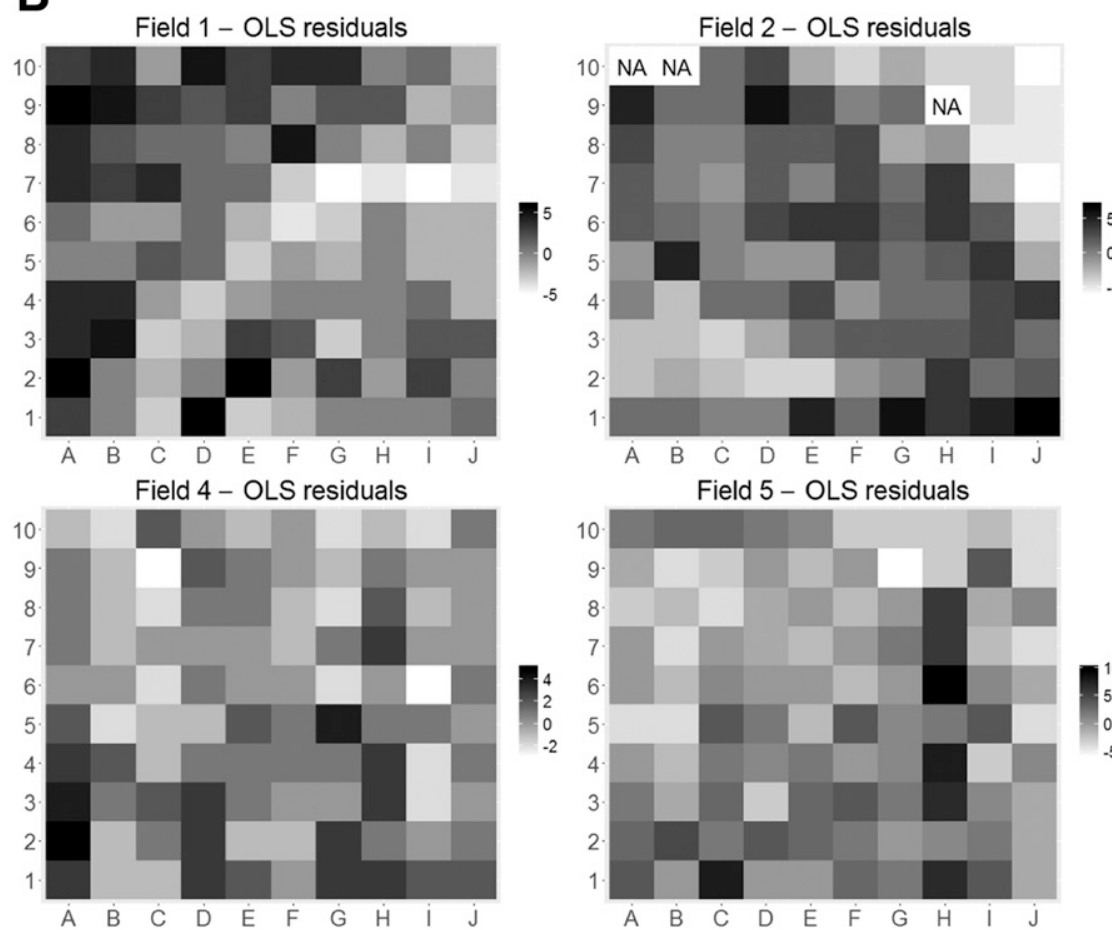

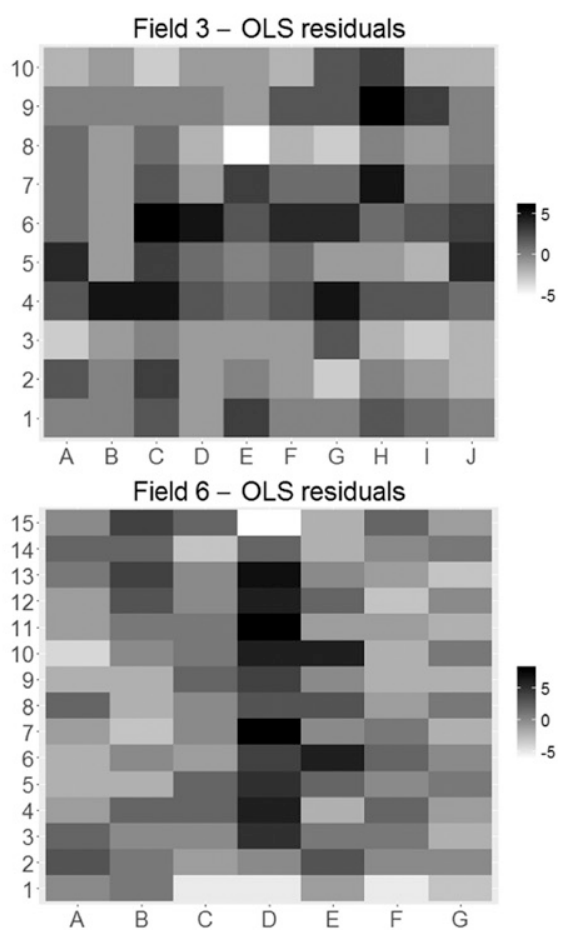

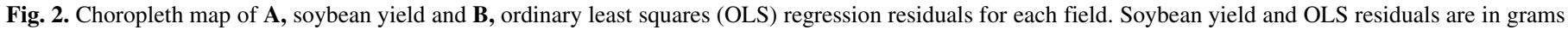
per soybean plant. NA represents missing values. Figure not drawn to scale. 
model had the greatest AIC values for all fields, except field 3, in which its value was the lowest (Table 2). Model comparison based on AIC suggested that the best fit to data from field 3 was the OLS regression model. Likewise, based on comparison of AIC values, a spatial error regression model was the best fit to data from fields 1,4 , and 5, and the spatial lag model performed best at fitting data from fields 2 and 6 (Table 2). Moreover, spatial coefficient parameters from the spatial error $(\lambda)$ and spatial lag $(\rho)$ models were significant $(P<0.05)$ after these models were fitted to data from all fields, except field 3 (Table 2). In field 3 , spatial coefficient parameters from the spatial error models $(\lambda=0.18, P=$ $0.290)$ and spatial lag $(\rho=0.21, P=0.196)$ were not significant (Table 2).

Effect of $\mathrm{H}$. glycines and M. phaseolina on soybean yield. Spatially correlated error terms in the standard OLS regression model were motivation for employing spatial regression models. When the spatial error and spatial lag models provided indistinguishable AIC values (Table 2), the spatial error model was
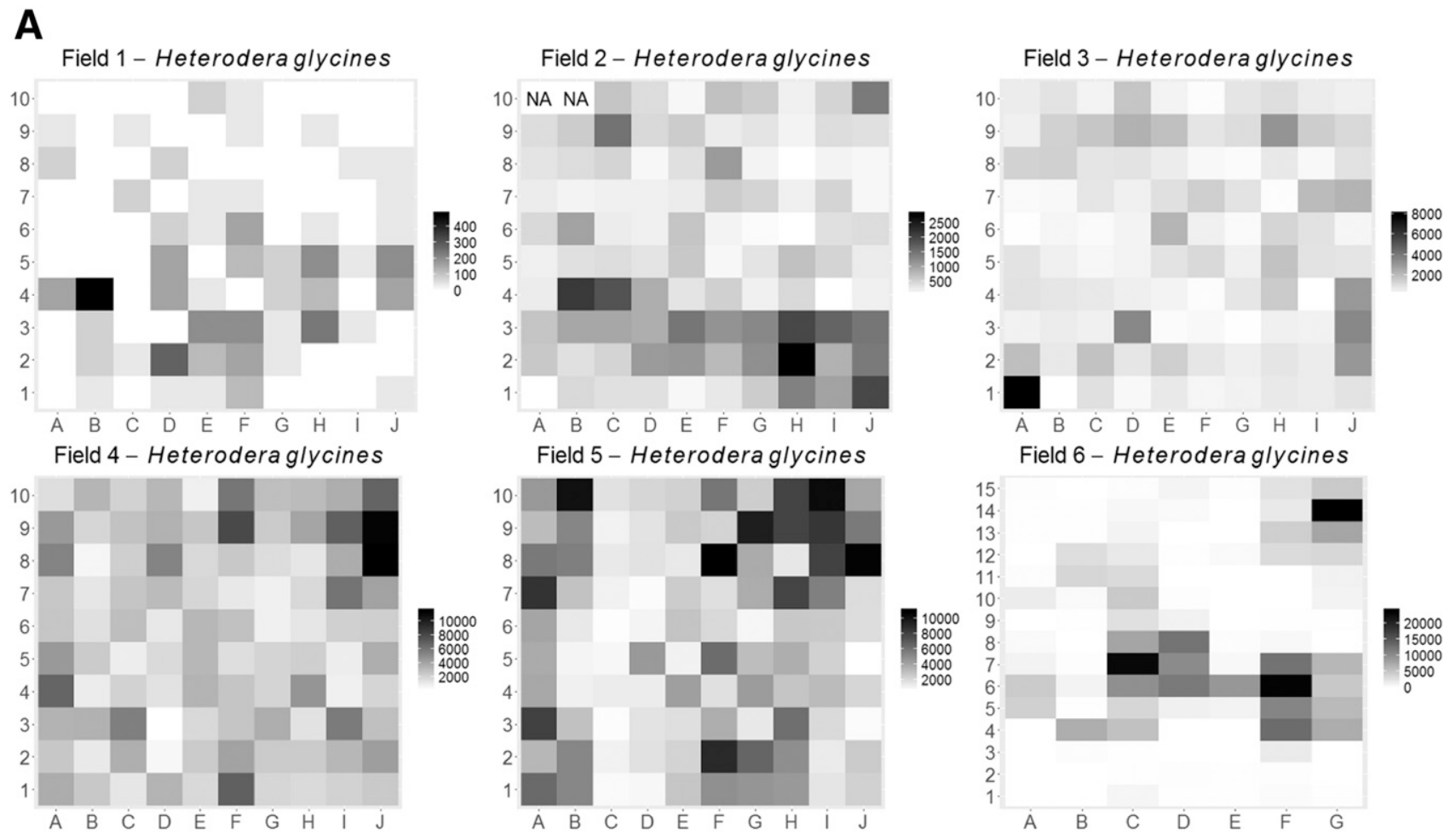

\section{B}

Field 1 - Macrophomina phaseolina
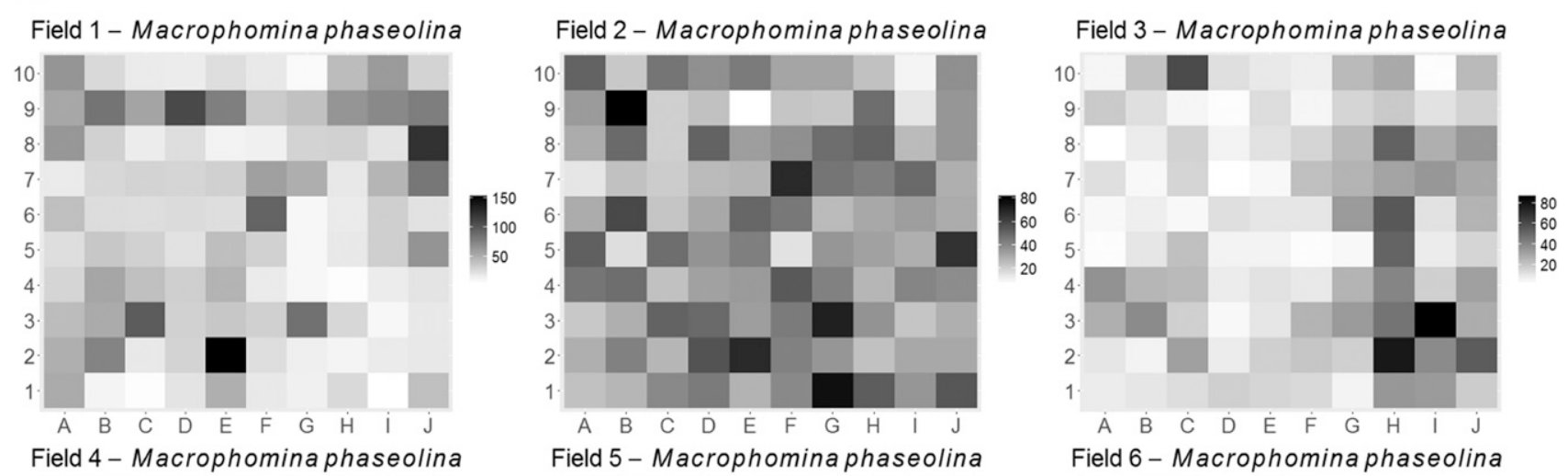

Field 4 - Macrophomina phaseolina
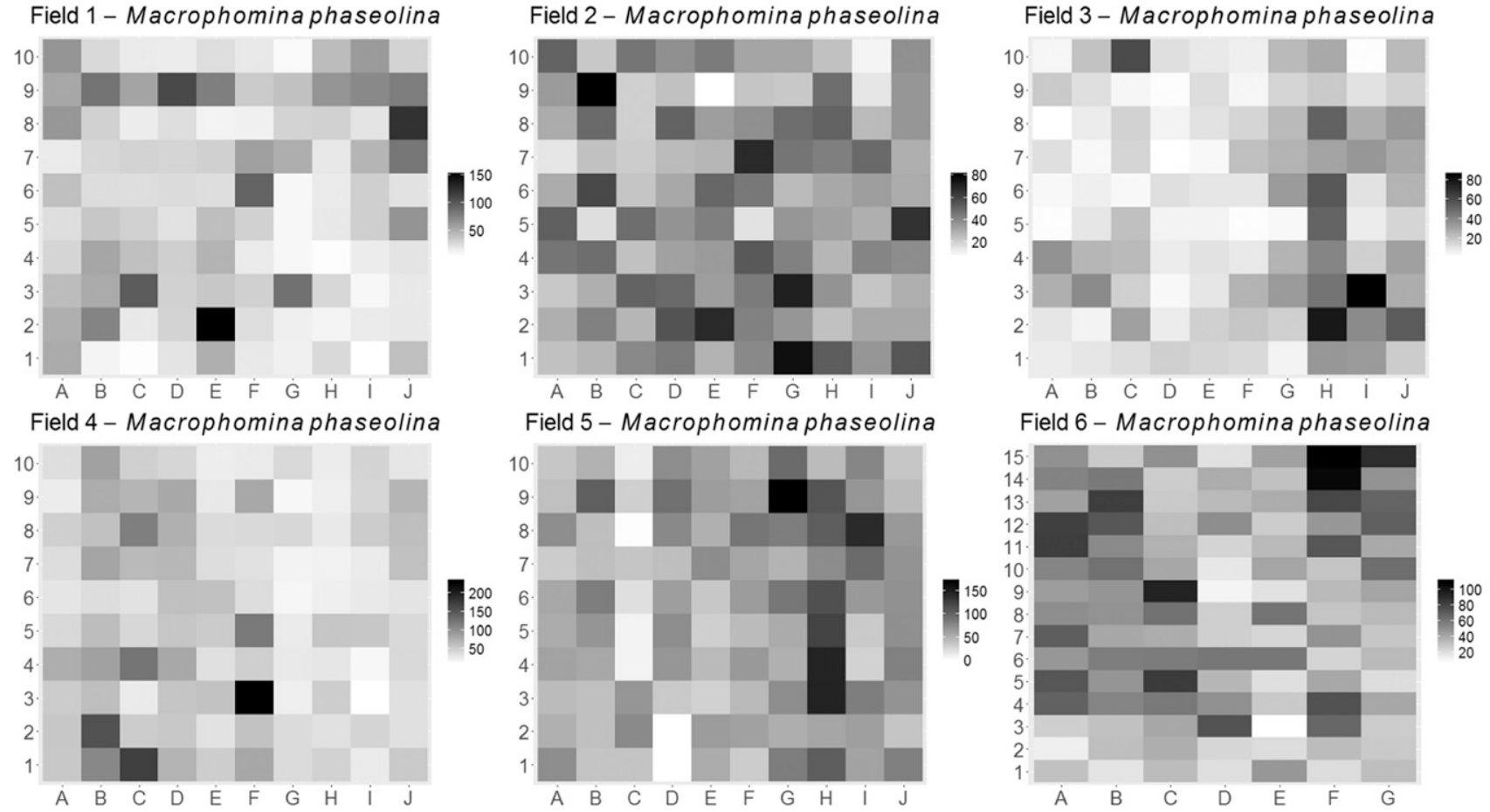

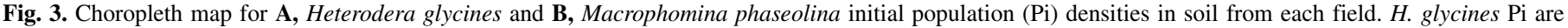
reported in eggs per $100 \mathrm{~cm}^{3}$ of soil and M. phaseolina Pi in colony forming units per gram of soil. NA represents missing values. Figure not drawn to scale. 
preferred to model the spatial structure in the error term (Bivand et al. 2013; Waller and Gotway 2004).

The main objective of the field study was to determine the presence (or not) of a significant interaction effect between $H$. glycines and M. phaseolina on soybean yield through linear multiple-regression models. A significant interaction effect between $H$. glycines and M. phaseolina on soybean yield was observed in fields 4 and 5, which were among fields that had, on average, Pi densities of $\mathrm{H}$. glycines and M. phaseolina $>2,000$ eggs per $100 \mathrm{~cm}^{3}$ of soil and $>45 \mathrm{CFU} / \mathrm{g}$ of soil, respectively (Tables 1 and 2). The spatial error model presented stronger evidence for the interaction effect than the OLS model; furthermore, significant interaction effect coefficients from field 4 and 5 were positive
(Table 2). At an $\alpha$ level of 0.05 , there was not sufficient evidence to conclude a significant interaction effect between $H$. glycines and M. phaseolina on soybean yield in fields 1,2,3, and 6 (Table 2).

Regression models from fields in which a significant interaction was not detected were fitted to data excluding the interaction coefficient, and results are presented in Supplementary Table S3 and Supplementary Figure S2. Spatial regression models were most appropriate to fit data from fields 1, 2, and 6, while the OLS regression model was the best fit for data from field 3. Coefficients for each soilborne pathogen were not significant $(P>0.05)$ in fields with low inoculum density (fields 1, 2, and 3) (Table 1). In field 1, the $H$. glycines coefficient was significant in the OLS model;

TABLE 2. Coefficients (Coef) and standard errors (SE) for the ordinary least squares (OLS), spatial error (SEM), and spatial lag (SLM) multiple-regression models and associated probability $(P)$ values for soybean yield regressed against initial population ( $\mathrm{Pi}$ ) of Heterodera glycines, Macrophomina phaseolina, and the interaction effect between these pathogens in each field ${ }^{\mathrm{a}}$

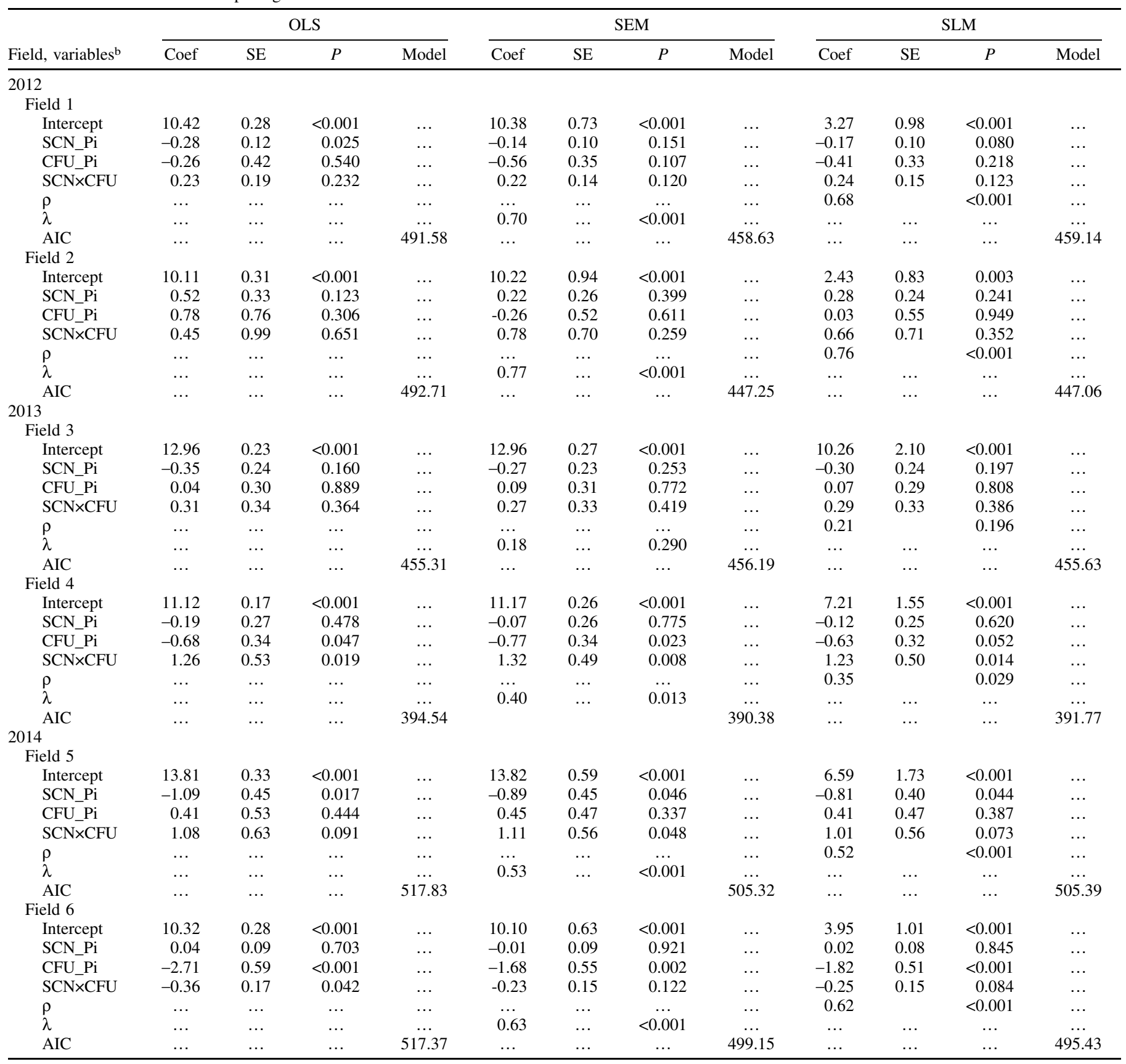

a OLS, SEM, and SLM multiple-regression models were used to fit data from each field.

b Field represents the year and field trial. SCN_Pi and CFU_Pi = natural log-transformed and mean centered $H$. glycines and M. phaseolina Pi, respectively, in soil; SCN $\times$ CFU = multiplicative interaction effect between the natural log-transformed and mean-centered SCN_Pi and CFU_Pi; $\rho=$ spatial parameter for the SLM; and $\lambda=$ spatial parameter for the SEM. Akaike information criterion (AIC) values were produced for OLS, SEM, and SLM. The lower the AIC value, the better the model. 
however, after accounting for spatial autocorrelation, the main effect for the nematode was no longer significant $(P>0.05)$ for either of the spatial regression models. Despite the high population densities of $H$. glycines in field 6 (Table 1; Fig. 3), its coefficient was not significant in the regression model. $M$. phaseolina Pi densities, however, significantly $(P<0.05)$ reduced soybean yield in field 6 .

Greenhouse experiments. The objective of the greenhouse study was to evaluate, through nematode reproduction and plant tissue fungal colonization, the combined effect of $H$. glycines and $M$. phaseolina infecting soybean under environmentally controlled conditions and to better understand the mechanism of the interaction effect detected in the field study.

For the greenhouse experiment with $\mathrm{H}$. glycines females per plant as dependent variable, the Poisson generalized linear model (GLM) was the best fit to data from experiment 1 , while a negative binomial GLM best fit the data from experiment 2.

The presence of $M$. phaseolina inoculum in coinfested treatments significantly $(P<0.05)$ reduced $H$. glycines females per plant (Fig. 4$)$. In the $H$. glycines-alone treatment, on average, over 100 females/ plant was recorded (Niblack et al. 2002); there were 111 and 127 H. glycines females/plant in experiments 1 and 2, respectively. In combination with the fungus, a mean of 66 and $86 \mathrm{H}$. glycines females/plant was recorded in experiments 1 and 2, respectively.

In the greenhouse study with $M$. phaseolina $\mathrm{CFU}$ per plant as dependent variable, negative binomial GLMM fit pooled data from experiments 1 and 2 the best. Counts of M. phaseolina CFU per plant in the presence of the nematode was not significantly different $(P=0.223)$ from the treatment with the fungus alone (data not shown). H. glycines and M. phaseolina were not recovered from uninoculated control pots.

\section{DISCUSSION}

The spatial distribution of soilborne pathogens may affect the spatial pattern of their damage (e.g., yield losses) on the host

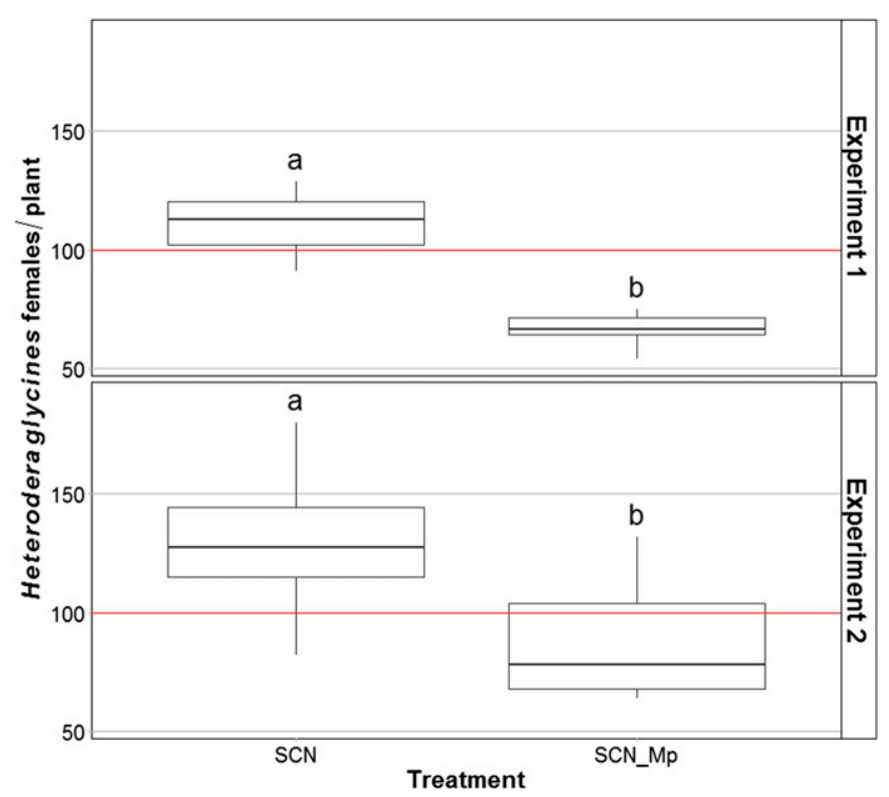

Fig. 4. Boxplot diagrams summarizing the distribution of Heterodera glycines female counts per plants as a function of treatments from two greenhouse experiments. Horizontal black lines inside the boxes represent the median value of $H$. glycines female counts per plants for each treatment: $\mathrm{SCN}=H$. glycines alone and SCN_Mp = soil coinfested with $H$. glycines and Macrophomina phaseolina. The top and bottom of the boxes are the 25 th and 75 th percentiles, respectively. Reference red line indicates $100 \mathrm{H}$. glycines females/ plant. Within each experiment, boxes with different letters differed significantly based on the Poisson (experiment 1) and negative binomial (experiment 2 ) generalized linear model at $\alpha=0.05$. Statistical analyses were performed on the log link scale; however, data are displayed on the original scale.
(Gavassoni et al. 2007; Hughes 1988). The spatial distribution of H. glycines (Francl 1986; Gavassoni et al. 2001, 2007) and M. phaseolina (Mihail 1989; Mihail and Alcorn 1987; Olanya and Campbell 1988, 1989) were previously described as aggregated. In all of the fields sampled in this study, both or either $H$. glycines and $M$. phaseolina $\mathrm{Pi}$ densities in soil were significantly aggregated. The spatial pattern of soybean yield and OLS residuals in each field were evaluated by means of Moran's $I$. When spatial dependence was significant, Moran's $I$ values were positive, indicating aggregation of the observations. Spatial aggregation in yield data has been previously reported and our results were similar (Kulkarni et al. 2008a,b; Liu et al. 2014, 2015). The use of spatial regression models allowed accounting for spatial autocorrelation whenever this was detected and more precisely testing the interaction effect between $H$. glycines and $M$. phaseolina on soybean yield.

In this study, a significant interaction effect between $H$. glycines and $M$. phaseolina on soybean yield was measured in two fields with high Pi densities of both pathogens. Under a significant interaction, interpretations of the main effects $(H$. glycines and M. phaseolina $\mathrm{Pi}$ densities) could be misleading, because the effect of one of the pathogens on soybean yield is dependent on the population density of the other pathogen. Even if the effect of one of the main terms is not significant in the regression model, under a significant interaction effect, the main terms are a linear function of each other (Kutner et al. 2004). Therefore, the main effects are inextricably linked under a significant interaction (Wallace 1983).

The significant interaction coefficients (in fields 4 and 5) were positive, suggesting that less soybean yield reduction took place under a significant interaction between $H$. glycines and $M$. phaseolina $\mathrm{Pi}$. We hypothesized that the positive interaction coefficient resulted from competition between these pathogens for similar ecological niches, a common phenomenon in disease complexes (Eisenback 1993; Lamichhane and Venturi 2015). To further evaluate this hypothesis, we conducted a greenhouse study in which $H$. glycines females per soybean plant were significantly reduced in the presence of $M$. phaseolina. Similar results have been previously reported in greenhouse interaction studies between Fusarium virguliforme (causal agent of sudden death syndrome of soybean) and $H$. glycines (Gao et al. 2006; McLean and Lawrence 1993). Similarly, Marburger et al. (2014) observed a negative association between $H$. glycines and $F$. virguliforme in commercial soybean fields in Wisconsin. However, the mechanisms by which $H$. glycines females per soybean plant were reduced in the presence of $M$. phaseolina were not evaluated in our greenhouse experiments and are yet to be investigated.

Many studies that evaluated soybean yield loss as an effect of $H$. glycines $\mathrm{Pi}$ identified fields with a wide range of population densities or artificially generated them (Chen et al. 2001; De Bruin and Pedersen 2008; Koenning 2000; MacGuidwin et al. 1995; Todd et al. 1995; Wang et al. 2000, 2003). In field 6, for example, an interaction effect between $H$. glycines and $M$. phaseolina was not significant. Similarly, the effect of $H$. glycines on yield was not significant despite the high Pi density. Close examination of the choropleth map for $H$. glycines Pi distribution in field 6 indicated a lack of range in the population density, which can affect the significance of a regression coefficient. Smrtnik et al. (2016) also observed an even distribution of $H$. glycines density in some fields with high populations from Ohio. The use of resistant and susceptible cultivars or a more unevenly distributed $H$. glycines $\mathrm{Pi}$ may have revealed yield reduction due to the nematode.

The choropleth map for $M$. phaseolina $\mathrm{Pi}$ in field 6, however, revealed a wide range. Reportedly, under hot $\left(>28\right.$ to $\left.30^{\circ} \mathrm{C}\right)$ and dry environmental conditions, M. phaseolina can cause charcoal rot and significantly reduce soybean yield (Gupta et al. 2012; Mengistu et al. 2015; Mihail 1989; Pearson et al. 1984). M. phaseolina Pi in field 6 significantly reduced soybean yield even when the environmental conditions typically reported for charcoal rot were not prevalent. Similar findings related to environment have been reported (Francl 
et al. 1988; Kendig et al. 2000; Mengistu et al. 2011) and suggest that there may be additional factors or a wider range of environmental conditions that favor charcoal rot.

In addition to evaluating the effects of $H$. glycines and M. phaseolina on soybean yield, we also described other aspects of the field biology of these soilborne pathogens. The RF (RF = $\mathrm{Pf} / \mathrm{Pi}$ ) is an indicator of the host's ability to support nematode reproduction and this ratio is commonly used to describe host status (Chen et al. 2001; De Bruin and Pedersen 2008; Koenning and Sipes 1998). In this study, soybean cultivars were labeled "resistant to $H$. glycines race 3", which frequently indicates that the plants have the PI 88788 source of resistance (Mitchum 2016). Fields infested with HG type 2.5.7, which by definition will reproduce on PI 88788 (Niblack et al. 2002), had greater RF compared with fields infested with HG type 5.7 (fields 4 and 5). Other studies have reported RF $>1$ on soybean cultivars with the PI 88788 source of resistance grown in fields infested with either HG type 0 or 2.5.7 (Chen et al. 2001; De Bruin and Pedersen 2008). Our results highlight the importance of determining the $H$. glycines virulence profile in a field and understanding the $\mathrm{HG}$ type test results, which can improve management strategies that rely on the use of soybean cultivars with resistance to $H$. glycines (Niblack 2005; Niblack et al. 2006, 2008; Tylka 2016).

Another element that may affect the RF is the nematode Pi density in soil, which is inversely related to the RF (Alston and Schmitt 1987; Bonner and Schmitt 1985; Chen et al. 2001; De Bruin and Pedersen 2008; Francl and Dropkin 1986; MacGuidwin et al. 1995). In the current study, the field with the lowest $H$. glycines $\mathrm{Pi}$ produced the largest $\mathrm{RF}$, reflecting a 15-fold increase in nematode population densities at the end of the season. Disease management to keep $H$. glycines population densities low and avoid the rapid increase that could easily reach damaging levels in one growing season must be made (De Bruin and Pedersen 2008). Extrinsic abiotic or biotic elements that may enhance or diminish the $H$. glycines life (and disease) cycle could positively or negatively affect the RF. In the current study, two fields (fields 4 and 5) with the lowest $H$. glycines RF were fields with the highest $M$. phaseolina $\mathrm{Pi}$ in soil. Several studies that evaluated interactions between cyst nematodes and fungal soilborne pathogens reported a reduction in nematode $\mathrm{RF}$ in the presence of the fungus (Gao et al. 2006; Hillnhütter et al. 2011; McLean and Lawrence 1993). This hypothesis was confirmed by results from our greenhouse study.

In all of the field trials in this study, M. phaseolina population densities in soil decreased at the end of the season. Previous studies reported similar results (Campbell and van der Gaag 1993; Francl et al. 1988; Zveibil et al. 2012). M. phaseolina survival in soil is affected by several abiotic and biotic factors such that this fungus is a poor soil competitor (Dhingra and Sinclair 1978; Elad et al. 1986; Zveibil et al. 2012). Therefore, sampling at the end of the season may underestimate $M$. phaseolina population densities in soil. On average, the CFU per gram of soil detected in this study fall in the ranges of previously reported $M$. phaseolina population densities (Francl et al. 1988; Kendig et al. 2000; Lopez-Nicora et al. 2016; Mengistu et al. 2009; Wrather et al. 1998, 2007).

Similarly, CFU per gram of tissue observed in this study were within the range of $M$. phaseolina propagule densities in soybean tissue previously reported (Mengistu et al. 2011,2013; Smith and Carvil 1997; Wrather et al. 2008). In our study, quantification of the fungus from soybean tissue was done from plants collected at harvest (i.e., soybean growth stage R8). At soybean growth stage $\mathrm{R} 8$, plants are senesced and saprophytic growth of M. phaseolina may affect the association measured between fungus population densities in tissue and soybean yield response (Mengistu et al. 2011). Additionally, in this study, high counts of CFU per gram of tissue were recorded in fields with low disease severity (fields 3 and 4). Previous studies have observed that lack of visible charcoal rot symptoms and vascular discoloration does not mean absence of $M$. phaseolina infection or reduction in yield due to the fungus (Kendig et al. 2000; Mengistu et al. 2007, 2013; Wrather et al. 2008).

In soybean commercial fields in Ohio, a significant interaction effect between $H$. glycines and $M$. phaseolina was detected via spatial regression analysis. The statistical interaction effect did not explain the mechanism by which these pathogens interact. Wallace (1983) recommended that, after significant interaction effects are detected in statistical models, further physiological studies be conducted. Additionally, regression analysis does not imply causation but relationship or association between the independent and the dependent variables (Kutner et al. 2004). Results from the greenhouse experiment suggested an explanation for the positive coefficient for the interaction term in the spatial regression models from the field study. The direct mechanisms by which $H$. glycines and $M$. phaseolina interact were not demonstrated in this study. Future studies must be conducted in the field and greenhouse, where experimental designs with appropriate treatments can be controlled to better understand the interaction between $H$. glycines and M. phaseolina on soybean production.

\section{ACKNOWLEDGMENTS}

We thank C. Martin and the soybean pathology and nematology lab members for technical assistance in these studies, and the producers and county educators that helped identify these fields and allowed us to sample.

\section{LITERATURE CITED}

Allen, T. W., Bradley, C. A., Sisson, A. J., Byamukama, E., Chilvers, M. I., Coker, C. M., Collins, A. A., Damicone, J. P., Dorrance, A. E., Dufault, N. S., Esker, P. D., Faske, T. R., Giesler, L. J., Grybauskas, A. P., Hershman, D. E., Hollier, C. A., Isakeit, T., Jardine, D. J., Kemerait, R. C., Kleczewski, N. M., Koenning, S. R., Kurle, J. E., Malvick, D. K., Markell, S. G., Mehl, H. L., Mueller, D. S., Mueller, J. D., Mulrooney, R. P., Nelson, B. D., Newman, M. A., Osborne, L., Overstreet, C., Padgett, G. B., Phipps, P. M., Price, P. P., Sikora, E. J., Smith, D. L., Spurlock, T. N., Tande, C. A., Tenuta, A. U., Wise, K., Wrather, J. A., and Young-Kelly, H. 2017. Soybean yield loss estimates due to disease in the United States and Ontario, Canada, from 2010 to 2014. Plant Health Prog. 18:19-27.

Alston, D. G., and Schmitt, D. P. 1987. Population density and spatial pattern of Heterodera glycines in relation to soybean phenology. J. Nematol. 19: 336-345.

Anselin, L., Bongiovanni, R., and Lowenberg-DeBoer, J. 2004. A spatial econometric approach to the economics of site-specific nitrogen management in corn production. Am. J. Agric. Econ. 86:675-687.

Barker, D., Culman, S., Dorrance, A., Fulton, J., Haden, R., Lentz, E., Lindsey, A., Lindsey, L., Loux, M., McCoy, E., Michel, A., Noel, J., Paul, P., Sulc, M., Thomison, P., Tilmon, K., and Witter, J. 2017. Ohio Agronomy Guide, 15 th ed. Bulletin 472. The Ohio State University, Columbus, $\mathrm{OH}$.

Bates, D., Maechler, M., Bolker, B., and Walker, S. 2015. Fitting linear mixedeffects models using lme4. J. Stat. Softw. 67:1-48.

Bivand, R., and Lewin-Koh, N. 2018. maptools: Tools for Handling Spatial Objects. R package version 0.9-3. https://CRAN.R-project.org/package=maptools

Bivand, R. S., Pebesma, E., and Gomez-Rubio, V. 2013. Applied Spatial Data Analysis with R, 2nd ed. Springer, New York, NY, U.S.A.

Bonner, M. J., and Schmitt, D. P. 1985. Population dynamics of Heterodera glycines life stages on soybean. J. Nematol. 17:153-158.

Bradley, C. A., and del Río, L. E. 2003. First report of charcoal rot on soybean caused by Macrophomina phaseolina in North Dakota. Plant Dis. 87:601.

Campbell, C. L., and van der Gaag, D. J. 1993. Temporal and spatial dynamics of microsclerotia of Macrophomina phaseolina in three fields in North Carolina over four to five years. Phytopathology 83:1434-1440.

Chen, S. Y., Porter, P. M., Orf, J. H., Reese, C. D., Stienstra, W. C., Young, N. D., Walgenbach, D. D., Schaus, P. J., Arlt, T. J., and Breitenbach, F. R. 2001. Soybean cyst nematode population development and associated soybean yields of resistant and susceptible cultivars in Minnesota. Plant Dis. 85:760-766.

Cummings, J. A., and Bergstrom, G. C. 2013. First report of charcoal rot caused by Macrophomina phaseolina in soybean in New York. Plant Dis. 97:1506.

De Bruin, J. L., and Pedersen, P. 2008. Response of old and new soybean cultivars to Heterodera glycines Ichinohe. Agron. J. 100:1347-1353.

Dhingra, O. D., and Sinclair, J. B. 1978. Biology and pathology of Macrophomina phaseolina. Imprensa Universitária Universidade Federal de Viçosa, Viçosa, Brasil. 
Eisenback, J. D. 1993. Interactions between nematodes in cohabitance. Pages 134-174 in: Nematode Interactions. M. W. Khan, ed. Chapman \& Hall, London, U.K

Elad, Y., Zvieli, Y., and Chet, I. 1986. Biological control of Macrophomina phaseolina (Tassi) Goid by Trichoderma harzianum. Crop Prot. 5:288-292.

ElAraby, M. E., Kurle, J. E., and Stetina, S. R. 2003. First report of charcoal rot (Macrophomina phaseolina) on soybean in Minnesota. Plant Dis. 87: 202.

Faghihi, J., and Ferris, J. M. 2000. An efficient new device to release eggs from Heterodera glycines. J. Nematol. 32:411-413.

Faraway, J. 2016. faraway: Functions and Datasets for Books by Julian Faraway. $\mathrm{R}$ package version 1.0.7. https://CRAN.R-project.org/package=faraway

Fehr, W. R., Caviness, C. E., Burmond, D. L., and Pennington, J. S. 1971. Stages of development descriptions for soybeans, Glycine max (L.). Merr. Crop Sci. 11:929-931.

Francl, L. J. 1986. Spatial analysis of Heterodera glycines populations in field plots. J. Nematol. 18:183-189.

Francl, L. J., and Dropkin, V. H. 1986. Heterodera glycines populationdynamics and relation of initial population to soybean yield. Plant Dis. 70: 791-795

Francl, L. J., Wyllie, T. D., and Rosenbrock, S. M. 1988. Influence of crop rotation on population density of Macrophomina phaseolina in soil infested with Heterodera glycines. Plant Dis. 72:760-764.

Gao, X., Jackson, T. A., Hartman, G. L., and Niblack, T. L. 2006. Interactions between the soybean cyst nematode and Fusarium solani f. sp. glycines based on greenhouse factorial experiments. Phytopathology 96: 1409-1415.

Gavassoni, W. L., Tylka, G. L., and Munkvold, G. P. 2001. Relationships between tillage and spatial patterns of Heterodera glycines. Phytopathology 91:534-545.

Gavassoni, W. L., Tylka, G. L., and Munkvold, G. P. 2007. Effects of tillage practices on dissemination and spatial patterns of Heterodera glycines and soybean yield. Plant Dis. 91:973-978.

Gearhart, K., Dugan, D., Grimes, J., Farley, L., Fisher, J., Burskey, C., and Dorrance, A. E. 2010. Survey of soybean diseases in the Ohio River Valley Region of Ohio during 2009. (Abstr.) Phytopathology 100:S39.

Gupta, G. K., Sharma, S. K., and Rameke, R. 2012. Biology, epidemiology and management of the pathogenic fungus Macrophomina phaseolina (Tassi) Goid with special reference to charcoal rot of soybean (Glycine max (L.) Merrill). J. Phytopathol. 160:167-180.

Hillnhütter, C., Sikora, R. A., and Oerke, E.-C. 2011. Influence of different levels of resistance or tolerance in sugar beet cultivars on complex interactions between Heterodera schachtii and Rhizoctonia solani. Nematology 13:319-332

Hughes, G. 1988. Spatial heterogeneity in crop loss assessment models. Phytopathology 78:883-884.

Kendig, S. R., Rupe, J. C., and Scott, H. D. 2000. Effect of irrigation and soil water stress on densities of Macrophomina phaseolina in soil and roots of two soybean cultivars. Plant Dis. 84:895-900.

Koenning, S. R. 2000. Density-dependent yield of Heterodera glycinesresistant and -susceptible cultivars. J. Nematol. 32:502-507.

Koenning, S. R., and Sipes, B. S. 1998. Biology. Pages 156-190 in: The Cyst Nematodes. S. B. Sharma, ed. Kluwer Academic Publishers, London, U. K.

Koenning, S. R., and Wrather, J. A. 2010. Suppression of soybean yield potential in the continental United States by plant diseases from 2006 to 2009. Plant Health Prog. 11:5.

Kulkarni, S. S., Bajwa, S. G., Robbins, R. T., Costello, T. A., and Kirkpatrick, T. L. 2008a. Effect of soybean cyst nematode (Heterodera glycines) resistance rotation on SCN population distribution, soybean canopy reflectance, and grain yield. Trans. ASABE 51:1511-1517.

Kulkarni, S. S., Bajwa, S. G., Rupe, J. C., and Kirkpatrick, T. L. 2008b. Spatial correlation of crop response to soybean cyst nematode (Heterodera glycines). Trans. ASABE 51:1451-1459.

Kutner, M. H., Nchtsheim, C. J., and Neter, J. 2004. Applied Linear Regression Models, 4th ed. McGraw-Hill, New York, NY, U.S.A.

Lamichhane, J. R., and Venturi, V. 2015. Synergisms between microbial pathogens in plant disease complexes: A growing trend. Front. Plant Sci. 6:385.

Liu, Z., Griffin, T., and Kirkpatrick, T. L. 2014. Statistical and economic techniques for site-specific nematode management. J. Nematol. 46:12-17.

Liu, Z., Griffin, T. W., Kirkpatrick, T. L., and Monfort, W. S. 2015. Spatial econometric approaches to developing site-specific nematode management strategies in cotton production. Precis. Agric. 16:587-600.

Lopez-Nicora, H. D., Simon, A. C. M., Dossman, B. C., Paul, P. A., Dorrance, A. E., Lindsey, L. E., and Niblack, T. L. 2016. Distribution and abundance of Heterodera glycines and Macrophomina phaseolina in Ohio. Plant Health Prog. 17:35-41.

MacGuidwin, A. E., Grau, C. R., and Oplinger, E. S. 1995. Impact of planting bell, a soybean cultivar resistant to Heterodera glycines, in Wisconsin. J. Nematol. 27:78-85.
Marburger, D., Conley, S., Esker, P., MacGuidwin, A., and Smith, D. 2014. Relationship between Fusarium virguliforme and Heterodera glycines in commercial soybean fields in Wisconsin. Plant Health Prog. 15:11-18.

McLean, K. S., and Lawrence, G. W. 1993. Interrelationship of Heterodera glycines and Fusarium solani in sudden death syndrome of soybean. J. Nematol. 25:434-439.

Melakeberhan, H., Avendaño, F., and Pierce, F. J. 2004. Spatial analysis of soybean yield in relation to soil texture, soil fertility and soybean cyst nematode. Nematology 6:527-545.

Mengistu, A., Ray, J. D., Smith, J. R., and Paris, R. L. 2007. Charcoal rot disease assessment of soybean genotypes using a colony-forming unit index. Crop Sci. 47:2453-2461.

Mengistu, A., Reddy, K. N., Bellaloui, N., Walker, E. R., and Kelly, H. M. 2013. Effect of glyphosate on Macrophomina phaseolina in vitro and its effect on disease severity of soybean in the field. Crop Prot. 54:23-28.

Mengistu, A., Reddy, K. N., Zablotowicz, R. M., and Wrather, A. J. 2009. Propagule densities of Macrophomina phaseolina in soybean tissue and soil as affected by tillage, cover crop, and herbicide. Plant Health Prog. 10:28.

Mengistu, A., Smith, J. R., Ray, J. D., and Bellaloui, N. 2011. Seasonal progress of charcoal rot and its impact on soybean productivity. Plant Dis. 95:1159-1166

Mengistu, A., Wrather, A., and Rupe, J. C. 2015. Charcoal rot. Pages 67-69 in: Compendium of Soybean Diseases. G. L. Hartman, J. C. Rupe, E. F. Sikora, L. L. Domier, J. A. Davies, and K. L. Steffey, eds. American Phytopathological Society Press, St. Paul, MN, U.S.A.

Mihail, J. D. 1989. Macrophomina phaseolina: Spatio-temporal dynamics of inoculum and of disease in a highly susceptible crop. Phytopathology 79: 848-855.

Mihail, J. D., and Alcorn, S. M. 1987. Macrophomina phaseolina: Spatial patterns in a cultivated soil and sampling strategies. Phytopathology 77: 1126-1131.

Mihail, J. D., and Taylor, S. J. 1995. Interpreting variability among isolates of Macrophomina phaseolina in pathogenicity, pycnidium production, and chlorate utilization. Can. J. Bot. 73:1596-1603.

Mitchum, M. G. 2016. Soybean resistance to the soybean cyst nematode Heterodera glycines: An update. Phytopathology 106:1444-1450.

Montgomery, D. C. 2013. Design and Analysis of Experiments, 8th ed. John Wiley \& Sons, Inc., New York, NY, U.S.A.

Niblack, T. L. 2005. Soybean cyst nematode management reconsidered. Plant Dis. 89:1020-1026.

Niblack, T. L., Arelli, P. R., Noel, G. R., Opperman, C. H., Orf, J. H., Schmitt, D. P., Shannon, J. G., and Tylka, G. L. 2002. A revised classification scheme for genetically diverse populations of Heterodera glycines. J. Nematol. 34:279-288.

Niblack, T. L., Baker, N. K., and Norton, D. C. 1992. Soybean yield losses due to Heterodera glycines in Iowa. Plant Dis. 76:943-948.

Niblack, T. L., Colgrove, A. L., Colgrove, K., and Bond, J. P. 2008. Shift in virulence of soybean cyst nematode is associated with use of resistance from PI 88788. Plant Health Prog. doi:10.1094/PHP-2008-0118-01-RS

Niblack, T. L., Lambert, K. N., and Tylka, G. L. 2006. A model plant pathogen from the kingdom Animalia: Heterodera glycines, the soybean cyst nematode. Annu. Rev. Phytopathol. 44:283-303.

Olanya, O. M., and Campbell, C. L. 1988. Effects of tillage on the spatial pattern of microsclerotia of Macrophomina phaseolina. Phytopathology 78: 217-221.

Olanya, O. M., and Campbell, C. L. 1989. Density and spatial pattern of propagules of Macrophomina phaseolina in corn rhizospheres. Phytopathology 79:1119-1123.

Pearson, C. A. S., Schwenk, F. W., Crowe, F. J., and Kelley, K. 1984. Colonization of soybean roots by Macrophomina phaseolina. Plant Dis. 68: 1086-1088.

R Core Team. 2018. R: A Language and Environment for Statistical Computing. R Foundation for Statistical Computing, Vienna, Austria. https:// www.R-project.org/

Romero Luna, M. P., Mueller, D., Mengistu, A., Singh, A. K., Hartman, G. L., and Wise, K. A. 2017. Advancing our understanding of charcoal rot in soybeans. J. Integr. Pest Manage. 8:1-8.

Schabenberger, O., and Pierce, F. J. 2002. Contemporary Statistical Models for the Plant and Soil Sciences. CRC press, Boca Raton, FL, U.S.A.

Smith, D., Chilvers, M., Dorrance, A., Hughes, T., Mueller, D., Niblack, T., and Wise, K. 2014. Charcoal rot management in the north central region. Ext. Pub. No. A4037. University of Wisconsin-Extension, Madison, WI, U.S.A. http://learningstore.uwex.edu/Assets/pdfs/A4037.pdf

Smith, G. S., and Carvil, O. N. 1997. Field screening of commercial and experimental soybean cultivars for their reaction to Macrophomina phaseolina. Plant Dis. 81:363-368.

Smrtnik, E., Niblack, T., Paul, P., Dorrance, A., and Bruns, D. 2016. Comparison of two soil sampling methods for estimating population densities of Heterodera glycines cysts. Plant Health Prog. 17:167-171. 
Stabler, B. 2013. shapefiles: Read and Write ESRI Shapefiles. R package version 0.7. https://CRAN.R-project.org/package=shapefiles

Su, G., Suh, S. O., Schneider, R. W., and Russin, J. S. 2001. Host specialization in the charcoal rot fungus, Macrophomina phaseolina. Phytopathology 91:120-126.

Todd, T. C. 1993. Soybean planting date and maturity effects on Heterodera glycines and Macrophomina phaseolina in southeastern Kansas. J. Nematol. 25:731-737.

Todd, T. C., Pearson, C. A. S., and Schwenk, F. W. 1987. Effect of Heterodera glycines on charcoal rot severity in soybean cultivars resistant and susceptible to soybean cyst nematode. J. Nematol. 1:35-40.

Todd, T. C., Schapaugh, W. T., Jr., Long, J. H., and Holmes, B. 1995. Field response of soybean in maturity groups III-V to Heterodera glycines in Kansas. J. Nematol. 27:628-633.

Tylka, G. L. 2016. Understanding soybean cyst nematode HG types and races. Plant Health Prog. 17:149-151.

Tylka, G. L., and Marett, C. C. 2014. Distribution of the soybean cyst nematode, Heterodera glycines, in the United States and Canada: 1954 to 2014. Plant Health Prog. 15:85-87.

Venables, W. N., and Ripley, B. D. 2002. Modern Applied Statistics with S, 4th ed. Springer, New York, NY, U.S.A.

Vittinghoff, E., Glidden, D. V., Shiboski, S. C., and McCulloch, C. E. 2012. Regression Methods in Biostatistics, 2nd ed. Springer, New York, NY, U.S.A.

Wallace, H. R. 1983. Interactions between nematodes and other factors on plants. J. Nematol. 15:221-227.

Waller, L. A., and Gotway, C. A. 2004. Applied Spatial Statistics for Public Health Data. John Wiley \& Sons, Inc., Hoboken, NJ, U.S.A.

Wang, J., Donald, P. A., Niblack, T. L., Bird, G. W., Faghihi, J., Ferris, J. M., Grau, C., Jardine, D. J., Lipps, P. E., MacGuidwin, A. E., Melakeberhan, H., Noel, G. R., Pierson, P., Riedel, R. M., Sellers, P. R., Stienstra, W. C., Todd, T. C., Tylka, G. L., Wheeler, T. A., and Wysong, D. S. 2000. Soybean cyst nematode reproduction in the north central United States. Plant Dis. 84:77-82.
Wang, J., Niblack, T. L., Tremain, J. A., Wiebold, W. J., Tylka, G. L., Marett, C. C., Noel, G. R., Myers, O., and Schmidt, M. E. 2003. Soybean cyst nematode reduces soybean yield without causing obvious aboveground symptoms. Plant Dis. 87:623-628.

Ward, M. D., and Gleditsch, K. S. 2008. Spatial Regression Models. Sage, Thousand Oaks, CA, U.S.A.

Wickham, H. 2009. ggplot2: Elegant Graphics for Data Analysis. SpringerVerlag, New York, NY U.S.A.

Wickham, H. 2016. tidyverse: Easily Install and Load 'Tidyverse' Packages. https://cran.r-project.org/web/packages/tidyverse/index.html

Winkler, H. E., Hetrick, B. A. D., and Todd, T. C. 1994. Interactions of Heterodera glycines, Macrophomina phaseolina, and mycorrhizal fungi on soybean in Kansas. J. Nematol. 26:675-682.

Wrather, J. A., Kendig, S. R., and Tyler, D. D. 1998. Tillage effects on Macrophomina phaseolina population density and soybean yield. Plant Dis. 82:247-250.

Wrather, J. A., Shannon, J. G., Carter, T. E., Bond, J. P., Rupe, J. C., and Almeida, A. M. R. 2008. Reaction of drought-tolerant soybean genotypes to Macrophomina phaseolina. Plant Health Prog. 9.

Wrather, J. A., Shannon, J. G., and Mengistu, A. 2007. Impact of soybean planting date on soil population density of Macrophomina phaseolina. Plant Health Prog. 8. https://apsjournals.apsnet.org/doi/10.1094/PHP-2007-091703-RS

Yang, X. B., and Navi, S. S. 2005. First report of charcoal rot epidemics caused by Macrophomina phaseolina in soybean in Iowa. Plant Dis. 89:526.

Young, L. D. 1996. Yield loss in soybean caused by Heterodera glycines. J. Nematol. 28:604-607.

Zeileis, A., and Hothorn, T. 2002. Diagnostic checking in regression relationships. R News 2/3:7-10. https:/CRAN.R-project.org/doc/Rnews/

Zveibil, A., Mor, N., Gnayem, N., and Freeman, S. 2012. Survival, hostpathogen interaction, and management of Macrophomina phaseolina on strawberry in Israel. Plant Dis. 96:265-272. 